\title{
Avaliação microbiológica da contaminação residual em diferentes tipos de alicates ortodônticos após desinfecção com álcool $70 \%$
}

Alessandre Cícero Venturelli*, Fernando César Torres**, Renata Rodrigues de Almeida-Pedrin***,

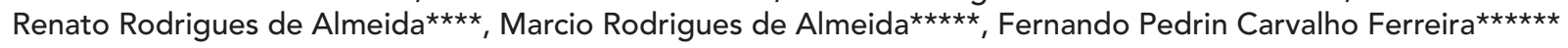

\section{Resumo}

Objetivo: o objetivo deste trabalho foi verificar, por meio de análises microbiológicas, a contaminação de diferentes tipos de alicates ortodônticos (139, Weingart, removedor de bandas e de corte distal) após a lavagem com água e sabão e fricção de álcool 70\% por um minuto. Métodos: todos os alicates foram, inicialmente, esterilizados em autoclave durante 20 minutos, a $121^{\circ} \mathrm{C}$ e pressão de $1 \mathrm{~atm}$. Após o atendimento ortodôntico, os alicates utilizados foram depositados individualmente em recipientes estéreis tipo béquer, fechados com papel kraft e transportados ao laboratório de Microbiologia. Esses alicates foram submetidos, numa primeira etapa, à coleta imediata de microrganismos e à semeadura para contagem de bactérias. Posteriormente, os mesmos alicates foram lavados com água corrente e sabão, e friccionados por um minuto com gaze (esterilizada) embebida em álcool 70\% (P/P). Novos testes bacteriológicos foram, então, realizados. Os alicates esterilizados do grupo controle foram submetidos aos mesmos testes bacteriológicos, todavia não haviam sido utilizados na clínica.

Resultados: os resultados demonstraram uma grande quantidade e variedade de bactérias residuais após a realização da desinfecção com o álcool 70\%. Conclusões: mesmo alicates que não são inseridos na cavidade bucal do paciente, como o 139, mas que são pegos pelo ortodontista, cujas luvas entram em contato com saliva e/ou sangue, devem ser esterilizados, pois somente a desinfecção não é suficiente para impedir a potencial infecciosidade desses instrumentos.

Palavras-chave: Ortodontia. Desinfecção. Esterilização. Microbiologia. Controle de infecção.

* Especialista em Ortodontia e Ortopedia Facial pela Faculdade de Odontologia de Lins - Unimep.

** Mestre e doutor em Ortodontia pela Faculdade de Odontologia de Bauru - USP. Professor dos cursos de graduação, especialização e mestrado em Ortodontia da Universidade Metodista de São Paulo - Umesp.

*** Mestre e doutora em Ortodontia pela Faculdade de Odontologia de Bauru - USP. Professora da disciplina de Ortodontia em nível de graduação da Faculdade de Odontologia de Lins - Unimep. Professora do curso de Especialização em Ortodontia da Faculdade de Odontologia de Lins - Unimep.

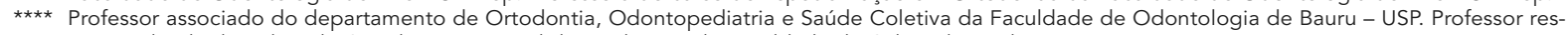
ponsável pela disciplina de Ortodontia em nível de graduação da Faculdade de Odontologia de Lins - Unimep.

$\star \star \star \star \star$ Mestre, doutor e pós-doutorado em Ortodontia pela Faculdade de Odontologia de Bauru - USP. Professor da disciplina de Ortodontia em nível de graduação da Faculdade de Odontologia de Lins - Unimep. Coordenador do curso de especialização em Ortodontia da Faculdade de Odontologia de Lins - Unimep.

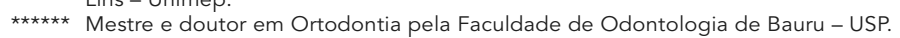




\section{INTRODUÇÃO}

O controle da transmissão de doenças infecciosas é uma preocupação antiga dos seres humanos, principalmente nas profissões da área da saúde, como a Odontologia ${ }^{10}$. Há algumas décadas, pouca importância era dada à esterilização de materiais e à utilização de barreiras contra a contaminação - como luvas, máscaras, gorros e óculos. Porém, a partir das décadas de 1970 e 1980, com o aumento significativo de casos de hepatite $\mathrm{B}$ e, mais tarde, dos casos de Síndrome da Imunodeficiência Adquirida (AIDS), foram obtidos novos conhecimentos sobre microrganismos patogênicos e sobre o meio de propagação de doenças infecciosas, reconhecendo-se a importância e a necessidade de maiores cuidados no controle da contaminação, tanto de profissionais como de pacientes ${ }^{5}$.

A Ortodontia tem se caracterizado pela alta rotatividade de pacientes, bem como pela multiplicidade de veículos transmissores de doenças (equipamentos, instrumental, mãos do operador, etc.), gerando sérios riscos de infecção ao clínico, aos auxiliares e aos pacientes ${ }^{16}$. Por trabalhar com pacientes de baixa idade, quando comparada a outras especialidades, muitos ortodontistas são relapsos no controle de infecção cruzada, por pensarem que seus pacientes fazem parte de um grupo de baixo risco. Esse fato vem contribuindo para que a Ortodontia se classifique como a segunda especialidade com mais casos de profissionais contaminados com hepatite B, perdendo somente para a Cirurgia Bucomaxilofacial. Esse quadro somente será revertido com uma maior preocupação em relação ao ciclo de infecção cruzada no consultório, adotando medidas de esterilização e desinfecção adequadas para cada tipo de material, local ou procedimento realizado. Para isso, talvez sejam necessários não somente investimentos em instrumentais e equipamentos, mas principalmente informação aos clínicos e auxiliares e conscientização de que a biossegurança é o fator mais importante no dia a dia clínico, uma vez que a Odontologia e, mais especificamente, a Ortodontia existem para solucionar problemas e não para causar doenças.

\section{Classificação de locais, instrumentos e procedimentos}

$\mathrm{Na}$ área da saúde, não há nenhuma atividade que apresente um quadro tão heterogêneo de detalhes, no que diz respeito ao controle de infecção, quanto a Odontologia, o que pode dificultar a tomada de decisões em relação aos cuidados na esterilização ou desinfecção de superfícies ou de instrumentos. As dificuldades poderão ser eliminadas ou extremamente reduzidas se o profissional, independentemente de sua especialidade, distinguir o ambiente de atuação e o risco potencial de transmissão de doenças dos instrumentos e dos materiais utilizados na clínica ${ }^{12}$.

As áreas ocupadas por profissionais e pacientes, e os instrumentos utilizados durante o atendimento, podem ser classificados em não-críticos, semicríticos ou críticos.

São consideradas não-críticas as áreas não ocupadas pelo paciente durante o atendimento, como sala de espera (realizar limpeza com água e sabão) Os artigos não-críticos são aqueles que entram em contato com a pele íntegra ou que não entram em contato direto com o paciente - como equipo, aparelhos de raios X, etc. (indica-se, para esses, limpeza e desinfecção de nível intermediário).

Semicríticas são as áreas restritas ao profissional e funcionários, como laboratório e lavanderia (exigem limpeza e desinfecção de nível intermediário). Os instrumentos semicríticos são aqueles que entram em contato com a mucosa íntegra e/ou pele não íntegra. Como exemplo, podemos citar as moldeiras, o material para exame clínico - pinça, sonda e espelho - e grande parte dos instrumentais utilizados em Ortodontia (necessitam de esterilização ou desinfecção de alto nível).

Áreas críticas são aquelas destinadas à assistência direta ao paciente, como clínica de atendimento e setor de esterilização (limpeza e desinfecção de nível intermediário). Já os artigos classificados como críticos são aqueles que penetram nos 
tecidos subepiteliais da pele e mucosa, sistema vascular ou outros órgãos isentos de microbiota própria. Ex.: porta-agulha, bisturi, cateteres, etc. (devem ser esterilizados).

Os procedimentos também recebem uma classificação semelhante: não-críticos são procedimentos em que não ocorre a presença de sangue, pus ou outras secreções orgânicas; são semicríticos quando existe secreção orgânica (saliva), mas sem perda de continuidade do tecido (geralmente o que ocorre em Ortodontia); e críticos quando há contaminação por sangue, pus ou perda da continuidade dos tecidos.

\section{Desinfecção}

Enquanto a esterilização ${ }^{4,7,13}$ é um processo no qual se consegue a total eliminação das formas de vida microbiana, a desinfecção é um processo de curta duração, que pode variar de alguns segundos a 30 minutos. No caso da desinfecção de alto nível, se obtém a destruição de todos os microrganismos, com exceção dos esporos. Fala-se em desinfecção de nível intermediário quando se consegue o extermínio da maioria dos microrganismos, o que inclui o bacilo da tuberculose, mas não todos os tipos de vírus nem esporos. Quando poucos microrganismos são eliminados por meio dos agentes químicos, nomeia-se de desinfecção de baixo nível.

A desinfecção em Odontologia é realizada por meio de soluções químicas, aplicadas tanto no consultório como em materiais e instrumentos que não podem ou não necessitam ser esterilizados, respectivamente por serem termossensíveis ou por não serem críticos no que diz respeito à contaminação ${ }^{11}$.

No consultório, a desinfecção é feita utilizando-se desinfetantes de nível médio ou baixo, empregados em todos os locais onde for possível encontrar microrganismos carreados pelos aerossóis oriundos de procedimentos clínicos ou das mãos da equipe odontológica, como bandeja, seringa tríplice, refletor, cabo do sugador, apoio da cabeça e braços da cadeira do paciente, mocho, armários, chão, etc. Nesses casos, podem ser utilizados os fenóis sintéticos, o hipoclorito de sódio ou o álcool 70\% (p/p) ou 77\% (v/v). Cabe ressaltar que o forramento de superfícies, comparado com a desinfecção, é um ganho de tempo dentro do consultório, além de ser bem mais seguro no controle da infecção cruzada.

Para a desinfecção de instrumentais, as soluções mais recomendadas são o glutaraldeído a 2\%, o formaldeído a 38\%, os fenóis sintéticos e o álcool $70 \%$. No entanto, somente o glutaraldeído pode ser considerado como um desinfetante de alto nível para materiais semicríticos. Para materiais não-críticos, desinfetantes de nível intermediário podem ser usados.

O tempo de imersão do material, tanto no glutaraldeído como no formaldeído, deve ser de 30 minutos, para uma adequada desinfecção. $\mathrm{O}$ instrumental deverá estar, previamente, limpo e seco e o recipiente com a solução deverá permanecer tampado. Deve-se enxaguar o instrumental, inclusive o interior das tubulações, com água potável ou esterilizada, de acordo com o nível crítico do material.

O glutaraldeído apresenta como vantagens: alta atividade bactericida, virulicida, fungicida e esporicida, com amplo espectro de ação; geralmente não é corrosivo; penetra no sangue, pus e resíduos orgânicos; tem vida útil longa; pode ser utilizado em instrumentos de borracha e plástico; é menos irritante e tóxico que o formaldeído; e é efetivo contra o Mycobacterium tuberculosis. Entretanto, podemos considerar como desvantagens: não é desinfectante de superfície fixa; é irritante aos tecidos, causando reação alérgica; descolora alguns metais; sua ação corrosiva pode aumentar conforme a diluição e o tempo de exposição à solução; é inativado pelo amoníaco e aminas primárias; e é mais tóxico que o fenol-sintético.

O formaldeído oferece como vantagens: ação bactericida, virucida, fungicida e esporicida; ação na presença do Mycobacterium tuberculosis; pode 
ser usado na desinfecção de acrílico, polipropileno, nylon, borrachas e metais; é menos corrosivo que o glutaraldeído; e tem vida útil longa. Porém, suas desvantagens são: causa irritação em contato com a pele; é tóxico quando inalado; tem odor desagradável; é inativado na presença da água; tem alto poder cancerígeno, não sendo aceito pelo Center for Diseases Control (CDC/EUA); e exposto à temperatura superior a $25^{\circ} \mathrm{C}$ sofre evaporação.

Os fenóis sintéticos são desinfetantes de nível intermediário, cujo tempo de exposição para superfícies é de 10 minutos, por meio de friçcão. Após esse procedimento, deve-se passar um pano úmido com água filtrada ou destilada e secar a superfície. No processo de desinfecção de instrumentos, o tempo de exposição é de 30 minutos, na concentração indicada pelo fabricante, geralmente na diluição aquosa de 1 para 50 . A paramentação com óculos, máscara, avental e luvas é importante para evitar efeitos tóxicos. Pode-se considerar como vantagens dos fenóis sintéticos: é bactericida, virulicida e fungicida; é aceito pela ADA (American Dental Association) como desinfetante de superfície fixa e de imersão; é efetivo na presença do Mycobacterium tuberculosis; não é corrosivo aos metais; não altera borracha e plásticos; é menos tóxico que o glutaraldeído; apresenta baixo custo; não é prontamente neutralizado pela presença de matéria orgânica; e tem ação residual. No entanto, suas desvantagens são: não é esporicida; deve ser preparado diariamente; pode degradar certos plásticos e corrói o vidro em exposições longas; acumula-se na superfície; é irritante à pele e aos olhos; é absorvido por materiais porosos; o efeito residual pode causar irritação tecidual; e é tóxico quando inalado.

\section{Álcool 70\%}

Os álcoois etílico e isopropílico são considerados desinfetantes de nível intermediário, empregados tanto em superfícies e instrumentos como na pele, como antisséptico. O efeito do álcool é a desnaturação de proteínas e a dissolução de gorduras, o que possibilita a atividade antimicrobiana, destruindo, por exemplo, a membrana do Mycobacterium tuberculosis e do HSV (vírus da herpes simples). Esse desinfetante não é efetivo na presença de matéria orgânica que, aderida à superfície do material, funciona como uma barreira mecânica à ação do álcool sobre os microrganismos. As soluções de álcool são germicidas, porém sua ação é imediata, com praticamente nenhuma ação residual. Quando associado ao iodo $(0,5$ a 1,0\% de iodo livre), o álcool pode apresentar um maior efeito residual e bactericida, mas essas soluções tornam-se irritantes para a pele. Com a associação de glicerina a $2 \%$, pode-se evitar o ressecamento da pele e a rápida evaporação do álcool.

A atividade antimicrobiana dos álcoois está condicionada à sua concentração em peso ou em volume em relação à água, que deve ser de $70 \%$ $(\mathrm{P} / \mathrm{P})$ ou $77 \%(\mathrm{~V} / \mathrm{V})$, respectivamente. Nessa concentração, o álcool não desidrata a parede celular do microrganismo, podendo penetrar no seu interior, onde irá desnaturar proteínas, fato que não ocorre quando se utiliza o álcool acima ou abaixo da concentração ideal.

Podemos citar como vantagens da desinfecção com o álcool 70\%: bactericida de ação rápida; ação na presença do Mycobacterium tuberculosis e virucida (somente para vírus lipofílicos); irritante leve; baixo custo; não-tóxico; incolor e não deixa resíduos. Como desvantagens, podemos considerar as seguintes características: não é esporicida; tem atividade diminuída na presença de matéria orgânica; danifica material de plástico, borracha ou acrílico; evapora rapidamente, com diminuição da atividade antimicrobiana em sangue seco, saliva e outras matérias orgânicas; não tem registro como desinfetante na EPA (Environmental Protection Agency) e não é aceito pela ADA como desinfetante de superfície fixa e instrumental; não apresenta ação contra vírus hidrofílicos; não tem ação residual; e é um desinfetante de nível médio.

O uso do álcool $70 \%$ é um método de desinfecção bastante popular, por ser um processo 
simples, relativamente rápido e de baixo custo para se realizar a destruição de microrganismos. No entanto, o uso do álcool, que é considerado um desinfetante de nível intermediário, acaba sendo, muitas vezes, superestimado, provavelmente devido à sua facilidade. Assim, instrumentais semicríticos (que devem ser preferencialmente esterilizados) e até instrumentais considerados críticos (que obrigatoriamente devem ser esterilizados) são apenas desinfetados com o álcool, produzindo a falsa impressão de se estar realizando um controle de infecção eficiente.

Em Ortodontia, a classificação dos materiais e instrumentais utilizados varia entre críticos e semicríticos. Sendo assim, a maioria dos alicates utilizados em Ortodontia requer esterilização. No entanto, sabe-se que nem sempre o clínico possui um estoque adequado de alicates para que esses possam ser corretamente esterilizados entre os atendimentos, muitas vezes devido ao custo do material e, algumas vezes, pelo receio de uma menor durabilidade desses mediante uma constante esterilização.

Com o intuito de verificar a eficácia da desinfecção de alicates ortodônticos, realizou-se uma análise microbiológica de diferentes tipos de alicates usados na clínica, lavados com água e sabão, e posteriormente friccionados com álcool 70\% durante 1 minuto.

\section{MATERIAL E MÉTODOS}

Para a realização desse experimento, foram selecionados 5 alicates de uso ortodôntico. Para o grupo experimental foram escolhidos 4 deles: 139, Weingart, removedor de bandas e de corte, utilizados como amostra para a avaliação microbiológica e verificação de contaminação após o uso na clínica de Ortodontia. Um alicate do modelo removedor de bandas foi mantido como grupo controle, permanecendo sem utilização na clínica. A experiência ocorreu num total de duas semanas, perfazendo uma amostra de 8 alicates no grupo experimental e 2 alicates no grupo controle.
Todos os alicates foram esterilizados ${ }^{9}$ em autoclave da marca Cristófoli, modelo Vitalle 12L, durante 20 minutos, a $121^{\circ} \mathrm{C}$ e pressão de $1 \mathrm{~atm}$, antes de serem utilizados em atendimento na clínica de Ortodontia do curso de Especialização em Ortodontia, da Faculdade de Odontologia de Lins (FOL) - Unimep.

Uma vez atendido o paciente, os alicates foram depositados, individualmente, em recipientes estéreis, tipo béquer, de $1.000 \mathrm{ml}$, fechados com papel kraft e transportados ao laboratório de Microbiologia da FOL. Os recipientes foram, então, abertos no laboratório, obedecendo-se às normas microbiológicas para não causar contaminação secundária nos alicates do grupo experimental e do grupo controle.

Os alicates do grupo experimental foram submetidos a duas etapas. A primeira consistiu na coleta imediata de microrganismos através de um swab (tubo de ensaio com meio de cultura para bactérias) e na semeadura para contagem de bactérias. Na segunda fase, os mesmos alicates foram lavados com água corrente e sabão, e friccionados por um minuto com gaze (esterilizada) embebida em álcool 70\% (P/P) e, então, novamente submetidos a testes bacteriológicos.

Para a coleta de agentes microbianos na superfície dos alicates que estiveram em contato com as estruturas bucais do paciente, foram utilizados swabs estéreis (Rayon) embebidos em solução salina fosfatada tamponada (PBS, phosfhate buffer solution), friccionados por 30 segundos. Imediatamente após a fricção dos swabs, esses foram semeados em triplicata na superfície de placas de Petri contendo ágar tripticase soja (TSA, Merck, Alemanha), a fim de se realizar a cultura. As placas semeadas foram incubadas em condições de aerobiose, a $37^{\circ} \mathrm{C}$, por 48 horas.

Após esse período, cada placa foi examinada por um só investigador, para a determinação do número de colônias bacterianas, com o auxílio de contador de colônias (CP602, Phoenix, Araraquara / SP). Posteriormente, essas placas foram 
submetidas à análise morfotintorial por meio da coloração de Gram. Os alicates do grupo controle foram autoclavados da mesma maneira e submetidos aos mesmos testes bacteriológicos, todavia não haviam sido utilizados junto aos pacientes.

\section{RESULTADOS}

Os resultados da contagem de Unidade Formadora de Colônia (UFC) e da Análise Morfotintorial, do grupo experimental nas fases 1 e 2, foram comparados utilizando-se parâmetros estatísticos de frequência absoluta e relativa (percentual) e estão demonstrados nas tabelas 1 e 2 e gráficos 1 a 5 .

\section{Análise Morfotintorial (Tab. 1)}

Enquanto os alicates do grupo experimental - que foram lavados e, então, desinfetados com álcool 70\% - permaneceram, de forma geral, contaminados, os alicates utilizados como grupo controle apresentaram-se isentos de crescimento de microrganismos, ou seja, estéreis.

\section{Unidades Formadoras de Colônia (Tab. 2)}

Nos alicates utilizados na clínica e desinfetados, observa-se que houve diminuição na quantidade de bactérias, no entanto permaneceram contaminados. No grupo controle, nenhuma colônia bacteriana foi detectada.

\section{DISCUSSÃO}

Muitos clínicos, e até mesmo uma grande parte dos especialistas em Ortodontia, apresentam deficiência no que diz respeito aos conhecimentos básicos de prevenção de doenças infecciosas ocupacionais ${ }^{5}$. Muitos ortodontistas são relapsos no controle da infecção cruzada, pois pensam que seus pacientes fazem parte de um grupo de baixo risco, por serem na maioria jovens. Além disso, consideram a Ortodontia uma especialidade não-invasiva. No entanto, foi demonstrado ${ }^{18}$ que os pacientes que frequentam a clínica ortodôntica são, predominantemente, adolescentes e adultos, sendo $21 \%$ crianças (1 a 10 anos), 52\% adolescentes (11 a 18 anos) e
TABELA 1 - Análise morfotintorial: grupos de bactérias presentes nos alicates do grupo experimental, antes ( $1^{\mathrm{a}}$ fase $)$ e após ( $2^{\mathrm{a}}$ fase $)$ a desinfecção com álcool 70\%.

\begin{tabular}{|c|c|c|}
\hline alicate & $1^{a}$ fase & $2^{a}$ fase \\
\hline removedor de banda & $\begin{array}{c}\text { Streptococcus sp, } \\
\text { Staphylococcus sp e } \\
\text { Bacilos } \mathrm{G}_{+}\end{array}$ & Staphylococcus $s p$ \\
\hline corte distal & $\begin{array}{c}\text { Streptococcus sp, } \\
\text { Bacilos G+, } \\
\text { Cocos G+ }\end{array}$ & Cocos G+e G- \\
\hline Weingart & $\begin{array}{c}\text { Streptococcus sp, } \\
\text { Staphylococcus sp e } \\
\text { Cocos G+ }\end{array}$ & $\begin{array}{c}\text { Streptococcus sp, } \\
\text { Staphylococcus sp e } \\
\text { Cocos } \mathrm{G}_{+}\end{array}$ \\
\hline 139 & Micrococos & Micrococos \\
\hline
\end{tabular}

TABELA 2 - Contagem de UFC: quantidade de bactérias presentes nos alicates do grupo experimental, antes e após a desinfecção com álcool 70\%.

\begin{tabular}{|ccc|}
\hline alicate & $1^{\text {a }}$ fase & $2^{\text {a }}$ fase \\
\hline removedor de banda & + de 500 UFC & de 400 a 500 UFC \\
\hline corte distal & de 400 a 500 UFC & de 300 a 400 UFC \\
Weingart & de 400 a 500 UFC & de 300 a 400 UFC \\
139 & de 200 a 300 UFC & de 100 a 200 UFC \\
\hline
\end{tabular}

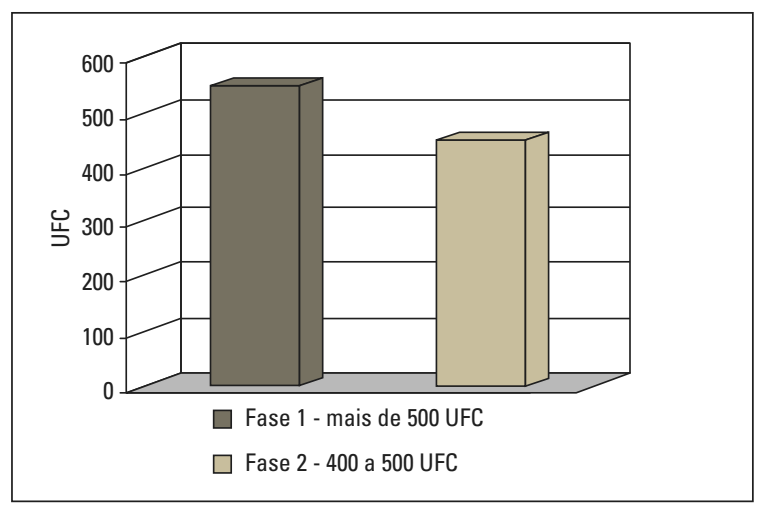

GRÁFICO 1 - Alicate removedor de banda.

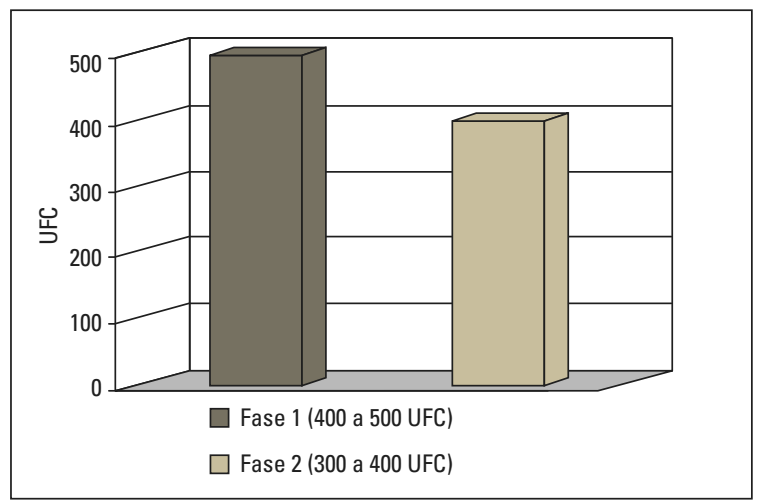

GRÁFICO 2 - Alicate de corte distal. 


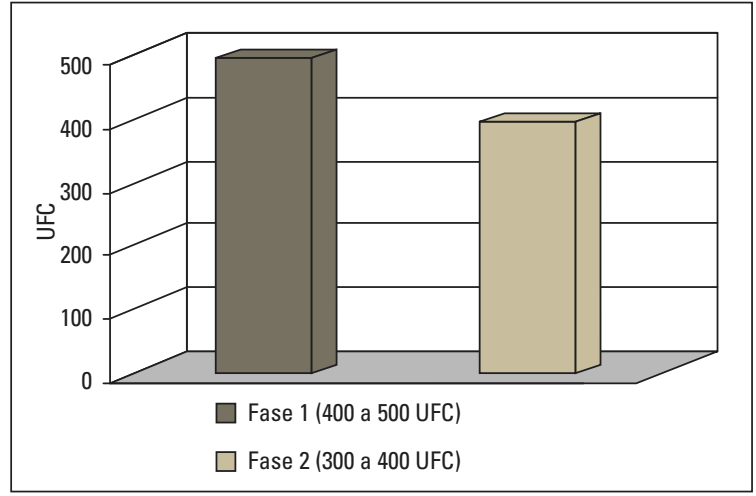

GRÁFICO 3 - Alicate Weingart.

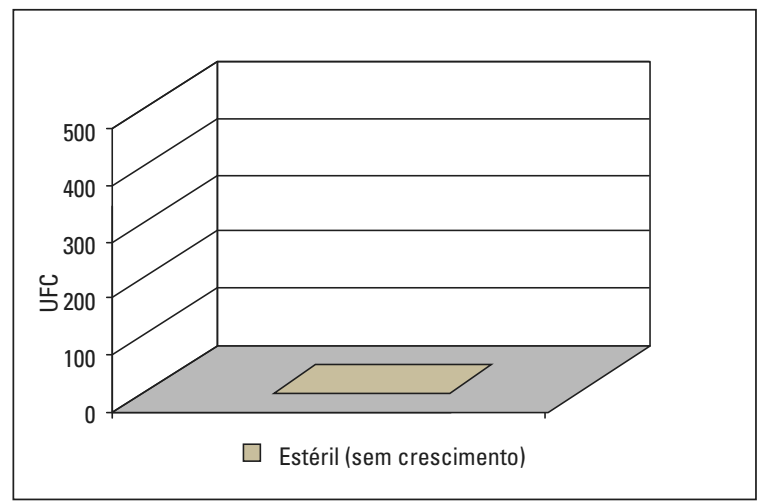

GRÁFICO 5 - Controle.

27\% adultos (maiores de 18 anos). Além disso, hoje em dia sabe-se que os microrganismos patogênicos não estão somente nos fluidos sanguíneos, que são menos comuns na Ortodontia, sendo importante frisar que muitas doenças podem ser transmitidas pelo contato com fluidos salivares.

A hepatite B, por exemplo, que é atualmente a segunda maior causa de mortalidade no mundo, só perdendo para o câncer de pulmão, apresenta um alto grau de transmissibilidade do vírus, devido à alta resistência desse, o qual permanece infeccioso por até 7 dias quando exposto em superfícies ${ }^{7}$. O HBV (vírus da hepatite B) pode ser transmitido por menos de $1 \mathrm{ml}$ de saliva e, obviamente, pelo sangue também. A inoculação do vírus pode ocorrer pelo contato de fluidos com mucosas, o que inclui olhos ${ }^{3}$, boca, etc.

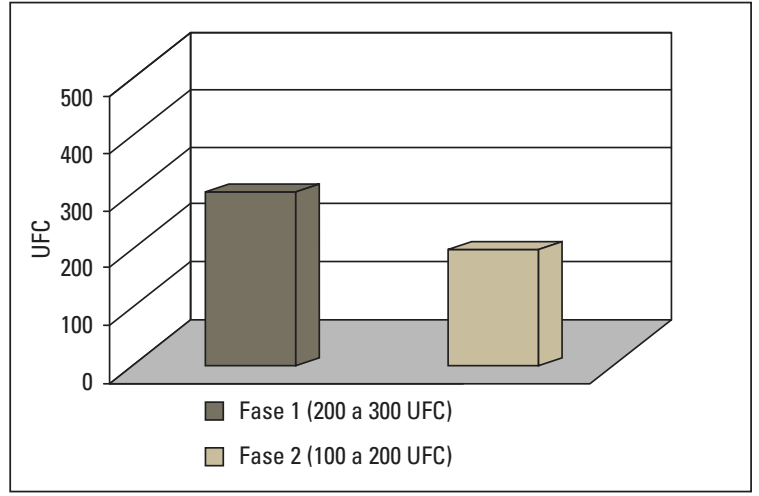

GRÁFICO 4 - Alicate 139.

Sabe-se que a abordagem ideal no consultório é que todos os pacientes e instrumentais sejam considerados como potencialmente capazes de transmitir doenças infecciosas. Sendo assim, o uso de barreiras e equipamentos de proteção individual - como luvas, máscaras, óculos, aventais e gorros - é de importância fundamental para a saúde do profissional, dos pacientes e da equipe de funcionários. No entanto, o odontólogo, muitas vezes, enxerga a adoção da esterilização dos instrumentos como algo que pode diminuir a rentabilidade e a eficácia do consultório, pela necessidade de investimentos em equipamentos e pela demanda de tempo, respectivamente.

Em 2000, foi evidenciado ${ }^{5}$ que uma grande parcela dos especialistas apresenta deficiência quanto à paramentação e conhecimento básico de prevenção de doenças infecciosas. Os métodos de esterilização mais empregados pelos especialistas são, em ordem de preferência, a estufa, substâncias químicas e autoclaves. A contraindicada utilização de esterilizadores químicos em larga escala, além do pequeno aproveitamento dos benefícios do calor úmido, são característicos entre os profissionais analisados.

Um erro frequente entre os ortodontistas é enxergar a desinfecção como uma alternativa à esterilização. Todo material que pode ser esterilizado jamais deve ser somente desinfetado. A facilidade de uso, o baixo custo e a toxicidade praticamente 
inexistente, associados à falsa impressão de se estar realizando um controle de infecção, levam muitos clínicos a utilizar, entre o atendimento de pacientes, o álcool 70\% em seus instrumentais. A rapidez do procedimento traz a vantagem de se necessitar de um menor estoque de materiais, o que, considerando-se o custo principalmente de alicates, pode baixar sobremaneira o investimento feito no consultório. O contraste é que o custo biológico dessa economia acaba sendo incomensuravelmente maior, podendo prejudicar a saúde de todas as pessoas que frequentam o consultório, além de seus amigos e familiares, também sujeitos à infecção de modo indireto.

O álcool é o desinfetante mais utilizado, porém, infelizmente, é o menos efetivo ${ }^{15}$. Já ficou comprovado que até a água é melhor do que o álcool para remoção de sangue e matéria orgâni$\mathrm{Ca}^{14}$, o que mostra a inadequação do álcool para a remoção de camadas de saliva dos instrumentos. Ele é classificado como ineficiente por possuir efeito mais bacteriostático do que bactericida contra formas vegetativas ${ }^{6}$. Outra desvantagem que contribui para a classificação do álcool como um desinfetante moderado é que ele possui uma rápida evaporação, sendo seu tempo de ação muito curto. Essas características fazem com que o álcool não seja aceito pela ADA como um material para desinfecção de instrumentos ${ }^{1}$.

Em vez do álcool, para a desinfecção de instrumentos a solução de melhor resultado é o glutaraldeído a $2 \%$, pois é o único que age na presença de matéria orgânica ${ }^{12}$. O glutaraldeído é fungicida, viruscida e bactericida em 10 minutos, tuberculicida em 30 minutos e esporicida em 10 horas. No entanto, é considerado potencialmente carcinogênico e exerce poder irritante nas mucosas oculares e respiratória, podendo provocar asma, bronquite e pneumonite.

Em estudo realizado na cidade de Curitiba ${ }^{8}$, concluiu-se que cerca de $27 \%$ dos ortodontistas entrevistados empregavam o glutaraldeído como forma de esterilização, usando tempo de exposição ao mesmo inferior a 10 horas; e 2,4\% dos ortodontistas entrevistados consideravam o álcool etílico $70 \%$ uma substância esterilizante. Mais de 50\% dos entrevistados empregavam métodos de desinfecção para instrumentais que deveriam ser esterilizados, podendo ocasionar infecção cruzada.

O presente estudo teve a intenção de avaliar o quão eficaz seria a desinfecção com o álcool 70\%, em diferentes tipos de alicates ortodônticos, uma vez que esses, provavelmente, são os instrumentos que mais sofrem desinfecção na clínica diária. Alguns alicates são usados externamente à cavidade bucal do paciente, pois apresentam a função de contornear o fio ortodôntico, realizar dobras etc. É o caso de alicates como o 139. Outros alicates são inseridos na boca do paciente, devido à função de acomodação do fio ortodôntico nos acessórios (alicate tipo Weingart), ou devido à função de corte do fio já dentro da boca (alicate de corte distal). Outros alicates, como o removedor de bandas ortodônticas, não raramente entram em contato com fluidos gengivais e sanguíneos, pela proximidade e pela pressão que podem exercer na gengiva para retirar a banda.

Assim, os testes realizados para verificar se, após o uso clínico desses variados alicates, seria suficiente a lavagem com água e sabão e a fricção com álcool indicaram que houve diminuição na variedade (análise morfotintorial) e na quantidade (contagem das unidades formadoras de colônias) de microrganismos, como era de se esperar. Contudo, todos os alicates do grupo experimental permaneceram com algum grau de contaminação, continuando a ser, do ponto de vista biológico, potencialmente infectantes.

Corroborando parcialmente com os resultados do presente estudo, em outra pesquisa ${ }^{2}$, utilizouse um lenço embebido em uma solução de álcool etílico associado à clorexidina, testado como método alternativo para a desinfecção contra o vírus da hepatite B e a bactéria Staphylococcus aureus, em alicates ortodônticos e superfície do mobiliário. $\mathrm{O}$ método foi mais efetivo para a bactéria do 
que para o vírus. Observou-se que a limpeza com água, escova e sabão diminuiu a bacteremia em alicates ortodônticos, mas somente a aplicação do lenço em alicates ortodônticos não pôde ser considerada segura, devido às dificuldades de acesso às reentrâncias do alicate, como articulação e ponta ativa, o que não permite o contato direto do lenço com a superfície contaminada.

Em trabalhos prévios, autores já aconselhavam a esterilização da maior parte dos materiais ortodônticos, o que incluía alguns alicates ${ }^{6}$. Foi recomendada a esterilização em autoclave de afastadores de lábios, potes Dapen, espelhos fotográficos, borrachas, elásticos e alicate removedor de banda, preconizando-se que todo o material e instrumental ortodôntico que entre em contato com sangue e saliva fosse esterilizado $^{6}$, visto que o vírus da hepatite B pode ser transmitido por instrumentais contaminados.

Já outros autores ${ }^{17}$ recomendam que bandas, pinças para ligaduras e alicates para remoção e confecção de bandas sejam sempre esterilizados; e que para instrumentos que dificilmente entram em contato com a boca - como alicates para o arco e chave de torque, entre outros - é permitida a desinfecção.

Os resultados do presente estudo demonstraram que mesmo alicates que não são inseridos na cavidade bucal do paciente, como o 139, mas são pegos pelo ortodontista, cujas luvas entraram em contato com saliva e/ou sangue, deveriam ser esterilizados, pois somente a desinfecção não foi suficiente para impedir a infecciosidade em potencial desses alicates.

\section{CONCLUSÕES}

Com base nos resultados dos experimentos do presente estudo e no levantamento bibliográfico realizado, foi possível concluir que:

1) A desinfecção feita por meio de lavagem com água e sabão, seguida de aplicação (fricção) de álcool 70\% (P/P) por um minuto, não demonstrou resultados satisfatórios para os alicates ortodônticos 139, Weingart, removedor de bandas e de corte distal, observando-se uma grande quantidade e variedade de bactérias após a realização desse procedimento.

2) O uso do álcool, em instrumentos ortodônticos que entram em contato direto ou indireto com a saliva e/ou o sangue, como único meio de promover o controle de infecção cruzada na clínica é contraindicado, devendo-se obrigatoriamente esterilizar tais materiais, preferencialmente em autoclave.

\title{
Microbiological evaluation in different kinds of orthodontic pliers after disinfection with $70 \%$ alcohol
}

\begin{abstract}
Aim: The aim of this study was to verify, by means of microbiological analysis, the contamination in different kinds of orthodontic pliers (Distal End Cutter, Bird Beak, Band Remover and Weingart), after washing with water and detergent and followed by disinfection with $70 \%$ alcohol for 1 minute. Methods: All the pliers were, initially, sterilized in autoclave for 20 minutes, at $121^{\circ} \mathrm{C}$ and $1 \mathrm{~atm}$ of pressure. After the orthodontic appointment, the pliers were adequately transported to Microbiology Laboratory and the evaluations of variety and quantity of bacteria were made. Afterward, the same pliers were washed with water and detergent, and rubbed with gauze with $70 \%$ alcohol $(p / p)$ for 1 minute. New bacteriological tests were done and compared to a control group of non utilized pliers. Results: Results showed a great quantity and variety of residual bacteria after the disinfection with alcohol. Conclusions: Even pliers not inserted in patient mouth, but only handed by clinician, should be sterilized, once merely disinfection is not an adequate method for infection control.
\end{abstract}

Keywords: Orthodontics. Disinfection. Sterilization. Microbiology. Infection control. 


\section{REFERÊNCIAS}

1. AMERICAN DENTAL ASSOCIATION. Council on Dental Materials and Devices. Council on Dental Therapeutics. Infection control in the dental office. J. Am. Dent. Assoc., Chicago, v. 97, p. 673-677, 1978.

2. ASENSI, M. D. et al. Desinfecção em Ortodontia: estudo de um método alternativo utilizando o lenço Bacti Buster Stepac LA em alicates ortodônticos e em superfície do mobiliário contra o vírus da hepatite $\mathrm{B}$ e a bactéria $\mathrm{S}$. aureus meticilinoresistente. J. Bras. Ortodon. Ortop. Facial, Curitiba, v. 4, n. 21, p. 265-270, maio/jun. 1999

3. BOND, W. et al. Transmission of type $B$ viral hepatitis via eye inoculation of a chimpanzee. J. Clin. Microbiol., Washington, D.C., v. 15 , no. $533-534,1982$

4. BRASIL. Ministério da Saúde. Coordenação de Controle de Infecção Hospitalar. Processamento de artigos e superfícies em estabelecimentos de saúde. Brasília, DF, 1999.

5. BUFFARA, W. M.; PORTELLA, M. Q. Controle de infecção em Ortodontia. Ortodontia, São Paulo, v. 33, n. 2, p. 77-85, maio/ago. 2000.

6. CAMPBELL, P. M.; PHENIX, N. Sterilization in the orthodontic office. J. Clin. Orthod., Boulder, v. 20, no. 10, p. 684-686, Oct. 1986.

7. CONSOLARO, A. A hepatite $B$ e a clínica ortodôntica. Ortodontia, São Paulo, v. 24, n. 2, p. 53-58, 1991.

8. CONTE, M. F. et al. Avaliação da utilização dos métodos de esterilização em Ortodontia. J. Bras. Ortodon. Ortop. Facial, Curitiba, v. 2, n. 10, p. 25-30, jul./ago. 1997.
9. COTTONE, J. A. et al. Practical infection control in Dentistry. Philadelphia: Lea \& Febiger, 1991.

10. FELDMAN, R. E.; SHIFF, E. R. Hepatitis in dental professionals. JAMA: Journal of the American Medical Association, Chicago, v. 232, no. 12, p. 1228-1230, June 1975.

11. GANDINI JÚNIOR, L. G. et al. Controle da infecção cruzada em Ortodontia: parte 2. Processamento, esterilização e controle de corrosão. Rev. Dental Press Ortodon. Ortop. Maxilar, Maringá, v. 2, n. 3, p. 80-85, maio/jun. 1997.

12. MANUAL de biossegurança. Bauru: Faculdade de Odontologia de Bauru, 2000.

13. MILLER, J. A. et al. A novel method of sterilizing orthodontic instruments. Aust. Orthod. J., Brisbane, v. 12, no. 3, p. 151-152, Oct. 1992.

14. MOLINARI, J. A. Comparisons of dental surface disinfectants. Gen. Dent., Chicago, v. 35, no. 3, p. 171-175, May/June 1987.

15. PAYNE, G. S. Sterilization and disinfection in orthodontic office: a practical approach. Am. J. Orthod. Dentofacial Orthop., St. Louis, v. 90, no. 3, p. 250-252, Sept. 1986.

16. SEKIJIMA, R. Contamination vehicles. J. Clin. Orthod., Boulder, v. 21, no. 5, p. 329-330, May 1987.

17. STARNBACH, H.; BIDDLE, P. A pragmatic approach to asepsis in the orthodontic office. Angle Orthod., Appleton, v. 50, no. 1, p. 63-66, Jan. 1980.

18. WOO, J. et al. Compliance with infection control procedures among California orthodontists. Am. J. Orthod. Dentofacial Orthop., St. Louis, v. 102, no. 1, p. 68-75, July 1992.
Endereço para correspondência

Fernando César Torres

Rua Nhu-Guaçu, 209, ap. 82, Campo Belo

CEP: 04.625-001 - São Paulo / SP

E-mail: fernando.torres@metodista.br 